\title{
VOCATIVO: ENUNCIAÇÃO E HISTÓRIA
}

\section{EDUARDO GUIMARÃES ${ }^{1}$}

\author{
Programa de Pós-Graduação em Linguística \\ Departamento de Linguística - Instituto de Estudos da Linguagem \\ Laboratório de Estudos Urbanos (LABEURB/NUDECRI) \\ Universidade Estadual de Campinas (Unicamp)
}

eduardo.guiduol.com.br

\begin{abstract}
Resumo. Este artigo analisa o funcionamento do vocativo. Para isso considera este funcionamento no modo como se configura a cena enunciativa. A análise procura mostrar como o vocativo, enquanto modo de projeção de um lugar social de alocutário, funciona a partir de uma terceira pessoa (um ELE). Nesta medida o vocativo, segundo o que aqui se faz, mostra que a constituição da relação entre um EU e um TU se faz a partir de uma relação entre um EU e um ELE. Esta análise sustenta, então, a posição segundo à qual a constituição do sentido é histórica e não dialógica.
\end{abstract}

Palavras-chave: vocativo; enunciação; agenciamento; cena enunciativa; lugares de enunciação.

\begin{abstract}
In this article it is analyzed the functioning of vocative. Therefore, its functioning is considered regarding the configuration of enunciative scene. The analysis allows us to show how vocative, while functioning as means of projection of speaker's social place, works from a third person position (a HE/SHE position). According to analytical procedures carried out, we came to the conclusion that the constitution of a relationship between "I" (first person) and "YOU" (second person) is produced upon a relationship between "I" and "HE/SHE" (third person). This way, the analysis supports the position according to which it is possible to assert that the constitution of meaning is historical and not dialogical.
\end{abstract}

Keywords: vocative; enunciation; agency; enunciative scene; places of enunciation.

\section{Introdução}

O objetivo deste texto é analisar os enunciados vocativos. Pouco se fala deste modo de enunciação. E o que em geral aparece como estudo do vocativo não diz quase nada sobre seu modo de funcionamento e seus sentidos específicos.

\footnotetext{
${ }^{1}$ Doutor em Linguística (USP). Docente no Instituto de Estudos da Linguagem da Universidade Estadual de Campinas, onde atua na Graduação e na Pós-Graduação. Na mesma universidade, também é pesquisador e coordenador do Laboratório de Estudos Urbanos (Labeurb), além de o atual Diretor da Editora da Unicamp.
} 
O que nossas gramáticas, em geral normativas, chamam de vocativo é caracterizado como um elemento que funciona sem conexão direta com o sujeito ou o predicado da sentença. Dos aspectos semânticos do vocativo pouco se fala, salvo que a expressão vocativa tem uma "função apelativa", ou que estabelece o ouvinte / receptor/ alocutário / destinatário do que se diz. Assim um vocativo como Prezados amigos, no início de uma carta, seria somente a constituição do que chamo o alocutário na cena enunciativa.

Se olhamos para o domínio da retórica, vamos encontrar algumas considerações que podem mostrar que há outros aspectos a serem considerados. Isto aparece no tratamento de uma figura de linguagem, a apóstrofe. Para Lausberg (1966), por exemplo,

a apóstrofe consiste em "separar-se" do público normal e dirigir a palavra a um segundo público eleito pelo orador de maneira surpreendente. Isto tem sobre o público normal um efeito patético, pois constitui no orador a expressão de um pathos que não pode canalizarse pelos caminhos normais de comunicação entre orador e público. A apóstrofe é, por assim dizer, um passo desesperado da parte do orador, impulsionado pelo pathos. Como segundo público na apóstrofe aparecem: o adversário, pessoas não presentes vivas ou mortas, coisas (pátria, leis, ofensas). (LAUSBERG, 1966, v. 2, p. 193)

A isto ele acresce: "a figura (a apóstrofe) não só implica distanciamento do público, como também distanciamento da coisa tratada" (ibidem, idem, p. 257, v. 2).

Por outro lado, Perelman e Tyteca (1958) colocam a apóstrofe nos procedimentos de comunhão com o auditório e dizem que o orador procura se confundir com seu auditório. Segundo eles, a apóstrofe é uma figura que favorece isso, tal como a personificação e a prosopopeia. E dizem algo muito interessante:

seu efeito "é igualmente obtido pela enálage da pessoa, a substituição do 'eu' ou do 'ele' pelo 'tu', que faz com que 'o auditório se acredita ver a si mesmo no meio do risco". (PERELMAN; TYTECA,1958, p. 241)

O que aqui podemos observar enquanto funcionamento linguístico é que a apóstrofe pode substituir, e o faz comumente, um nome (ELE) por um TU. É este aspecto que me interessa no presente trabalho, pois não estou interessado em falar das relações argumentativas que podem, sem dúvida, estar, nos casos específicos, concernidas.

\section{Primeira aproximação}

Tomemos um caso comum de enunciado vocativo, o que aparece quando interpelamos alguém, durante uma conversa, uma aula etc. Tomo, como exemplo, uma pergunta a um aluno, cujo nome represento por uma só letra:

(1) D, você já terminou a correção dos exercícios? 
Tomemos também um e-mail enviado a uma pessoa, cujo nome represento também por uma só letra:

(2) L, você já enviou o livro?

O que se poderia dizer sobre este funcionamento? Vejamos:

1) O enunciado vocativo é constituído por um nome próprio ( $D$, no primeiro caso, e $L$, no segundo);

2) Ao se enunciar este nome próprio, estabelece-se, nos dois casos, um alocutário específico: uma certa pessoa, em cada um dos casos.

Ou seja, para se constituir o alocutário nestes casos, a enunciação apresenta um nome de pessoa como vocativo. Com o enunciado vocativo, constitui-se um TU (alocutário) a partir de uma nomeação, em outras palavras, a partir de uma enunciação que "precede" o funcionamento do vocativo. Essa nomeação atribui, no caso, um nome a alguém. Estamos diante de um ELE constituído por essa nomeação. Sem este ELE, sem este nome, não há como enunciar este vocativo. $\mathrm{O}$ acontecimento do enunciado vocativo significa um ELE que é tomado (agenciado) em alocutário. Um outro aspecto a ser observado é que o enunciado vocativo se articula por incidência com os outros enunciados. Não se trata nem de uma relação de dependência, nem de coordenação. $O$ enunciado, $D$ ou $L$, incide, no caso, sobre o texto em que está integrado. A enunciação do vocativo incide sobre o texto significando a enunciação de um locutor para um alocutário.

\section{O funcionamento enunciativo do vocativo}

Para levar à frente esta primeira aproximação, tomemos alguns casos de enunciados vocativos, em acontecimentos de enunciação diversos.

Vamos considerar aqui alguns textos para facilitar minha reflexão:

(T1) Andorinha Andorinha, de Manuel Bandeira;

(T2) Me dá um dinheiro aí, de Homero Ferreira;

(T3) José, de C. Dummond de Andrade;

(T4) Discurso, de Juscelino Kubitschek na inauguração de Brasília;

(T5) Discurso, de José Sarney na discussão constitucional em 1988.

Em todos estes textos, encontramos este modo de enunciar conhecido como vocativo:

a) andorinha, andorinha, no texto de Bandeira:

"Andorinha, andorinha, minha canção é mais triste:

- Passei a vida à toa, à toa."

b) Ei, você aí, no texto de Homero Ferreira:

"Ei, você aí

Me dá um dinheiro aí

Me dá um dinheiro aí!" 
c) José?, repetidas vezes, no poema de Drummond:

"E agora, José?

A festa acabou,

a luz apagou,

o povo sumiu,

a noite esfriou,

e agora, José?"

d) Brasileiros!, no discurso de JK:

"Brasileiros!"

e) Brasileiras e brasileiros, no discurso de Sarney:

"Brasileiras e Brasileiros,"

O que podemos observar nestes casos é que, tal como consideramos acima, todos os nomes que aparecem na enunciação vocativa aparecem ali como um modo de tomar aqueles ali significados como os alocutários na cena enunciativa. Tomemos o caso do discurso de Juscelino Kubitschek. Quando, no acontecimento enunciativo, se diz "Brasileiros!", há um lugar social de locutor que é apresentado no acontecimento como presidente da república falando aos que são aí agenciados como alocutários. Tem-se um locutor-presidente que enuncia a um alocutário-brasileiro. Caso semelhante é o do texto do presidente José Sarney, em que aparece brasileiras e brasileiros. Neste último caso, a relação é entre um locutor-presidente e os alocutários al-brasileira e al-brasileiro.

Por outro lado, no poema "Andorinha", o poeta nos fala das andorinhas, na primeira estrofe ("andorinha lá fora está dizendo..."). Andorinha é aí um ELE. Na segunda estrofe, ela é agenciada como alocutária do locutor-poeta.

Os três casos observados acima colocam, todos, a questão de como pensar a relação nome e vocativo. Ou, posto de outro modo, como pensar a relação entre designação (no sentido que uso este termo), referência e vocativo?

De outra parte, no texto "Me Dá um Dinheiro Aí", encontramos um vocativo expresso pela forma você. Em verdade, este movimento do vocativo com a forma você se apresenta no texto com outros elementos que agenciam o alocutário; a expressão é "Ei, você aí!", ou seja, o vocativo se apresenta com outros elementos que marcam este apelo ao TU $(E i$ e $a \hat{l})$.

Se consideramos esta possibilidade de um vocativo com a forma você, vemos, no entanto, que não parece razoável parafrasear andorinha, andorinha, por você, você. Como não seria razoável considerar que, nos dois casos que tomamos no início, se poderia substituir $D$ ou $L$ por você. O que parece razoável é uma paráfrase como:

Andorinha, andorinha, você deve saber, minha cantiga é mais triste...

Ou seja, a forma você não é um substituto imediato de um nome como vocativo. Em outras palavras, o vocativo com um nome não é simplesmente uma forma de interpelar o alocutário (um TU). É uma forma de agenciar alguém, ou algo, em alocutário. No enunciado em questão aqui, uma forma que talvez funcione como susbtitutiva do 
vocativo andorinha, andorinha seria você aí, para usarmos o modo do vocativo no T2. Teríamos:

\author{
Andorinha lá fora está dizendo: \\ -Passei o dia à toa, à toa. \\ Ei, você aí, você aí, minha canção é mais triste: \\ -Passei a vida à toa, à toa.
}

O modo possível para esta paráfrase mostra que o vocativo precisa se reportar àquele que foi significado anteriormente no texto por andorinha (o você reescritura andorinha). E mesmo assim, ei, você aí, você aí traz uma polissemia que não se põe do mesmo modo que andorinha, andorinha. Este você aí pode ser um modo de interpelar a quem mais estiver ali presente. Ou seja, como disse logo acima, a enunciação vocativa não é simplesmente uma forma de constituir um TU, um alocutário.

A enunciação vocativa é um modo de agenciar alguém em alocutário. Neste caso, a relação não é, então, entre Locutor (L) - Alocutário (AL); é entre um lugar social de locutor (l-x) - e um lugar social de alocutário (al-x). A relação que se constitui pelo enunciado vocativo é entre o lugar social de locutor e o lugar social de alocutário. Isso significa que o processo de significação daquele designado (ou referido) pelo nome é parte do sentido do vocativo. Ou seja, a enunciação vocativa não é simplesmente a marcação do TU da cena enunciativa; é o modo de constituição de alguém como aquele (um lugar social) para quem se fala na cena. A história da constituição deste lugar significa no vocativo. Há, pois, na cena enunciativa, os elementos da constituição histórica do sentido da palavra que aparece como enunciação vocativa.

\title{
4. Vocativo e a partilha da nomeação
}

Observemos mais de perto o caso dos discursos de Juscelino Kubitschek (T4), de um lado, e de José Sarney (T5), de outro. No primeiro caso temos o enunciado vocativo "Brasileiros!", e, no segundo, o enunciado vocativo é "brasileiras e brasileiros". Jamais seria possível dizer "Vocês!" no texto de Juscelino e nem "vocês e vocês" no texto de Sarney. Por outro lado, vê-se que, em T4, o agenciamento das pessoas em lugar social de alocutário é feita pela forma Brasileiros que, como forma não marcada no par brasileiros e brasileiras, pode significar o conjunto dos que podemos chamar de brasileiros $e$ brasileiras. Por outro lado, vê-se que são dois vocativos distintos por uma razão muito particular: o modo de agenciar alguém em alocutário-x identifica, em cada caso, de modo diferente. No primeiro caso (discurso de JK), identifica globalmente; no caso do discurso de Sarney, identifica, por outro lado, através da identificação distinta de homens e mulheres. Portanto, observar o vocativo, é uma forma de observar, de modo muito específico, o funcionamento designativo dos nomes.

$\mathrm{O}$ vocativo mostra como um nome tem um sentido identificador, e estamos tomando este termo no sentido de Rancière (1994, p. 43): "um nome identifica, ele não classifica". Os nomes significam não porque referem. Significam por identificar, produzir uma "partilha" 2 do mundo. E é a partir desta partilha que o vocativo funciona, e mais que

\footnotetext{
${ }^{2}$ No sentido que o termo tem para Rancière.
} 
isso, o vocativo pode afetar o próprio modo como a partilha se dá. Este é um modo muito específico de funcionamento do vocativom que está constitutivamente marcado pelo processo semântico histórico-político.

Dos vocativos tomados para esta análise, falta falar do vocativo no poema "José" de Carlos Drummond de Andrade. José é um nome próprio. Observemos mais especificamente o funcionamento do vocativo no poema.

1. O nome do poema é tomado a um nome de pessoa. E assim o poema é sobre José.

2. a) José é, no corpo do poema, em todos os casos, um enunciado em uma enunciação vocativa. Assim, o poema é significado como para José, é dito a José.

b) Essa enunciação vocativa se apresenta:

- em perguntas - a maior parte

- em afirmação (três vezes)

- em afirmações exclamativas:

"Mas você não morre, você é duro, José!"

"você marcha, José!"

- em uma afirmação simples:

"e agora, José, Minas acabou"

c) $\mathrm{O}$ enunciado vocativo aparece:

- no fim de enunciado, por exemplo:

"E agora, José?

A festa acabou,"

- no início de enunciado, por exemplo

"você marcha, José!

José, para onde?"

3. O enunciado vocativo José se relaciona ao nome José.

4. O enunciado vocativo José é reescriturado pela expressão vocativa você no $7^{\circ}$ verso:

"E agora, José?

A festa acabou,

a luz apagou,

o povo sumiu,

a noite esfriou,

e agora, José?

e agora, você?

você que é sem nome," 
Se o que dissemos acima sobre a partilha produzida pelo nome e sua relação com o vocativo faz sentido, o vocativo em "E agora, José?" não é uma referência, não é um substituto de $t u$. É a tomada de alguém que tem o nome José como alocutário pessoal. Isto, se de algum modo mostra algo do funcionamento do nome próprio, mostra também que o nome próprio funciona diferentemente do nome comum. Aspecto que também podemos ver pela relação que há entre um nome próprio e o que conhecemos por aposto ${ }^{3}$. E, na medida em que o vocativo é um nome próprio, poderíamos pensar que quem está interpelado em alocutário é alguém, cujo nome é José.

Mas este vocativo, que se diz por uma enunciação do nome próprio, traz sentidos que se produzem exatamente pelo nome próprio específico que nele aparece. Sem entrar em grandes detalhes, podemos observar que este José é tanto uma pessoa qualquer (o que está significado pelo fato de José ser um dos nomes de pessoa mais comuns no Brasil), quanto o próprio poeta (isto fica significado, por exemplo, por "E agora, José, Minas acabou"). Estes aspectos do sentido do nome próprio e da construção do poema são decisivos na constituição do sentido deste vocativo: algo que jamais se encontraria na forma $t u$, ou você. Em outras palavras, quando o vocativo é um nome próprio, entra em jogo aspectos do sentido que não se reduzem à figura do TU, e nem derivam do sentido do TU. A constituição do alocutário-x está, neste caso, valendo-se do sentido produzido historicamente para o nome próprio.

Podemos ainda nos perguntar sobre o que significa a reescrituração do vocativo José pelo vocativo você. Você que é, em seguida, reescriturado por José, novamente. É o que se tem na parte inicial do poema:

E agora, José?
A festa acabou,
a luz apagou,
o povo sumiu,
a noite esfriou,
e agora, José?
e agora, você?
você que é sem nome,
que zomba dos outros,
você que faz versos,
que ama, protesta?
e agora, José?

Do ponto de vista do vocativo, podemos dizer que este movimento de reescrituração mostra o funcionamento de agenciamento do alocutário-x na relação com o locutor-x, e mostra, de forma particular, algo que já dissemos: a enunciação do vocativo se constitui a partir da relação com um ELE, com uma partilha específica (política) das coisas.

Façamos atenção mais específica a este funcionamento do sentido do nome no vocativo, olhando agora por um outro ângulo. Voltemos aos vocativos "Brasileiros!" e "Brasileiras e Brasileiros". Comecemos pelo discurso de Juscelino. Em um certo momento do texto encontramos:

\footnotetext{
${ }^{3}$ Sobre a relação nome próprio e funcionamento apositivo ver, por exemplo, Guimarães $(2014 ; 2012)$.
} 
Brasileiros! Daqui, do centro da Pátria, levo o meu pensamento a vossos lares e vos dirijo a minha saudação. Explicai a vossos filhos o que está sendo feito agora. É sobretudo para eles que se ergue esta cidade síntese, prenúncio de uma revolução fecunda em prosperidade. Eles é que nos hão de julgar amanhã.

Brasileiros! É um vocativo. Em seguida, encontramos um vos (vos dirijo), que reescritura Brasileiros!, anaforicamente. Ou seja, agenciam-se aqueles a quem se designa por brasileiros e depois se significa estes assim designados por vós (vossos). E logo antes, no parágrafo que precede o acima citado, encontramos:

Esta cidade, recém-nascida, já se enraizou na alma dos brasileiros; já elevou o prestígio nacional em todos os continentes; já vem sendo apontada como demonstração pujante da nossa vontade de progresso, como índice do alto grau de nossa civilização; já a envolve a certeza de uma época de maior dinamismo, de maior dedicação ao trabalho e à Pátria, despertada, enfim, para o seu irresistível destino de criação e de força construtiva.

Nesta passagem, temos o nome brasileiros, que não é reescriturado por algo como o vós, mais acima. Mas, tal como o vocativo "Brasileiros!", também designa (identifica) estes mesmos que são significados como brasileiros no vocativo.

Por outro lado, no texto de Sarney, encontramos o vocativo Brasileiras $e$ Brasileiros, que se apresenta iniciando 5 blocos de seu discurso. Isto por si mostra, como vimos, uma diferença entre o vocativo no texto de Sarney e o vocativo no texto de Juscelino. Tal como no texto de JK, encontramos os nomes brasileiras e brasileiros fora do funcionamento vocativo em:

Com a franqueza com que sempre me dirigi às brasileiras e brasileiros, devo admitir que nós vivemos uma fase de múltiplas, acentuadas e grandes dificuldades.

Estes aspectos mostram como o vocativo, ao ser dito por um nome que assim projeta como alocutário aquilo, aqueles que são designados por esse nome, não funciona como uma segunda pessoa. A partir do sentido designativo produzido pela enunciação, vê-se que enunciar "brasileiros!" (JK) ou "brasileiras e brasileiros" (Sarney) não é simplesmente a constituição de um alocutário. É a constituição deste alocutário a partir do modo de significar aqueles que têm o que chamamos nacionalidade brasileira. Não se trata simplesmente de constituir um TU, trata-se de identificar alguém com brasileiro e a partir disso agenciá-lo como TU. E a designação do nome (no caso "brasileiros", ou "brasileiras e brasileiros") aparece assim como constituindo o que temos chamado de lugar social do alocutário (o que representamos como alocutário-x - al-x), em correlação direta com o lugar social do locutor (o que representamos por locutor-x - 1-x).

\section{O vocativo e a cena enunciativa}

Consideremos os vocativos andorinha, andorinha e Brasileiros ou Brasileiras $e$ Brasileiros. Como tratar o fato de que andorinha designa algo e toma este algo como um 
TU, agencia o designado por andorinha como um TU? Tal como dissemos, trata-se de um lugar social de alocutário. Isto nos faz repensar a caracterização das figuras da cena enunciativa: O Locutor e seu correlato Alocutário; o locutor-x e seu correlato alocutário$\mathrm{x}$; o enunciador.

Retomemos o modo como definimos cada uma destas figuras ${ }^{4}$. Locutor é, na cena enunciativa, o lugar que diz (seu correlato é o Alocutário); alocutário-x é o lugar do qual se diz (seu correlato é o alocutário-x); enunciador é o lugar de dizer. Tomando estas definições, o vocativo agencia alguém (designado por um nome, por exemplo) como o correlato do lugar social do qual se diz. Precisamos, então, dar uma maior clareza a estas três definiçõos.

$\mathrm{Na}$ cena enunciativa o Locutor é o lugar que diz, o lugar que significa o acontecimento como um presente do próprio dizer que diz; e seu correlato, o Alocutário, é o lugar para o qual se diz, enquanto lugar do próprio presente do dizer do Locutor. $\mathrm{O}$ Alocutário é assim um correlato direto do Locutor.

Já o locutor-x, o lugar social do qual se diz, não tem um correlato direto, pois, o lugar do qual se diz é o lugar considerado marcado pelo que do acontecimento está significado como seu passado, como seu memorável. Nesta medida, o alocutário-x nunca é um correlato direto do locutor-x. O próprio dizer do locutor-x e do Locutor dividido em locutor- $\mathrm{x}$, ao se significar como um certo $\mathrm{x}$, historicamente configurado, significa um outro x que se configura como seu alocutário na cena. Consideremos o caso do discurso de Juscelino Kubitschek: neste caso, a correlação que fica significada na cena enunciativa é de um lugar de presidente que fala ao lugar dos brasileiros historicamente constituído. Assim, o sentido do lugar-presidente é diretamente relacionado a um outro lugar, o de brasileiro, tomados neste acontecimento como locutor-x, de um lado, e alocutário-x, de outro.

Esta análise sugere uma especificação da relação do espaço de enunciação e a cena enunciativa. O espaço de enunciação é espaço de distribuição política das línguas para seus falantes. Os falantes são aqueles que são constituídos pela relação das línguas que os afeta historicamente. Consideremos agora o acontecimento de enunciação que se dá pelo funcionamento das línguas neste espaço. Este funcionamento agencia o falante (de português do Brasil, por exemplo) em locutor. E de que figura de locutor falamos aqui, ao analisarmos o vocativo? De um lugar social de locutor (um 1-x), que se constitui a partir de uma partilha do mundo politicamente constituída tomada como locutorpresidente, locutor-poeta, e como alocutário- $\mathrm{x}$, al-andorinha, al-brasileiros, ou albrasileiras e brasileiros.

Assim, no acontecimento de enunciação, temos (o sinal $>$ > indica a "passagem" do agenciamento $)^{5}$ :

\footnotetext{
${ }^{4}$ Sintetizamos aqui o que está em Guimarães (2002).

${ }^{5} \mathrm{O}$ funcionamento do vocativo coloca de modo muito direto que não se pode considerar a cena enunciativa a partir de uma posição dialógica, tal como não se pode considerar o espaço de enunciação como dialógico, já que nele não há TU, só há EU. O falante é constituído pela relação com as línguas e com outros falantes (isto está na própria definição de espaço de enunciação (GUIMARÃES, 2002)). Uma consequência disso é observar que as divisões das figuras enunciativas (cena enunciativa) não têm as características habitualmente consideradas nas teorias da polifonia.
} 


\section{ESPAÇO DE ENUNCIAÇÃO}

\section{ACONTECIMENTO DE ENUNCIAÇÃO}

\section{LÍNGUAS - FALANTES AGENCIA F $>$ > 1-x - ELE $>>$ al-x}

Ao mesmo tempo, quando l-x enuncia para al-x, ele enuncia como L para AL. E enuncia de um lugar de dizer $\mathrm{E}$ (enunciador). Isto mostra a enunciação como se fosse individual. $\mathrm{O}$ locutor se caracteriza por uma disparidade que lhe é constitutiva. Assim vêse como o vocativo constitui o agenciamento da relação do locutor-x / alocutário-x. O que sugere que podemos considerar que o locutor-x tem uma relação particular com a configuração dos falantes no espaço de enunciação. Para pensar isso, é necessário levar em conta o modo como se dá a história das línguas no espaço de enunciação (aspecto que não é objeto deste texto).

A disparidade do locutor, acima referida, própria das relações na cena enunciativa, tem a ver com a temporalidade própria de um acontecimento. O Locutor, que se mostra como quem diz, está dividido pela história que agencia o lugar do qual se diz, que se apresenta assim como um lugar social do dizer. Por outro lado, o alocutário-x não é um lugar idêntico ao do locutor-x. Esta diferença é própria do percurso do dizer no acontecimento. A análise do vocativo mostra como seu funcionamento dá conta desta disparidade. O vocativo é assim um funcionamento específico (não o único), no acontecimento, da configuração desta disparidade. E é esta disparidade que dá ao dizer de um locutor a possibilidade de se movimentar na projeção de seu alocutário-x. $O$ alocutário-x se apresenta como uma projeção do locutor-x. E, enquanto projeção, não coincide com os lugares de alocutário que podem ser agenciados quando da interpretação dos enunciados de um acontecimento de enunciação. Ao contrário, esta projeção é a constituição de um lugar em que o locutor-x projeta o alocutário, para que, assim, compreenda, neste lugar, o que diz o locutor-x. Um outro aspecto a ser considerado é que o impacto do passado no presente projeta um futuro no qual o alocutário-x se apresenta como sendo sempre este projetado pelo locutor-x. É isso que, por exmeplo, se dá com o caso de Brasileiros!

E se dá também com o caso de andorinha, andorinha que, no fundo, significa algo como: me compreendam do lugar da andorinha para quem agora digo. É preciso compreender esta projeção como uma construção metafórica (observemos que o discurso indireto da voz da andorinha - andorinha lá fora está dizendo passei o dia á toa à toa? é também metafórico). E isto pode ser visto com clareza, se observamos o funcionamento do vocativo como algo que, na cena enunciativa, constrói este lugar de alocutário-x. E que lugar especificamente é este? É o da ave à qual o poeta se refere na primeira estrofe? Não, é o lugar, na falta de um outro modo de dizer, ao qual se reporta a alocução dos desiludidos com a própria vida, daqueles que se sentem inúteis.

O que fica significado neste vocativo (andorinha, andorinha) coloca o que consideramos como o lugar do qual se "lê", se "interpreta" um acontecimento, como não coincidente com este alocutário- $\mathrm{X}$ projetado pelo locutor-X no acontecimento. Esta 
questão nós a tratamos em Guimarães (2013). Segundo o que ali dissemos, a relação de "leitura" inclui uma disparidade temporal, ela não é do mesmo tempo que o tempo do acontecimento do dizer.

O termo usado na semântica da enunciação, notadamente por Ducrot e nos trabalhos da semântica argumentativa, para se referir a esta "multiplicidade" de figuras da enunciação, é polifonia, termo retirado e re-configurado a partir de Bakhtin, por Ducrot. Para mim, que tenho usado o termo polifonia, redefinindo-o como uma divisão do Locutor, parece suficiente e necessário, agora (a análise do vocativo vai fortemente nesta direção), dizer que se trata da disparidade do locutor, da sua divisão produzida pelo agenciamento político da enunciação própria do acontecimento da enunciação: a cena enunciativa é caracterizada pela disparidade do agenciamento político da enunciação. Falar da disparidade, não só coloca diretamente que há uma não unicidade do locutor, mas também que a distribuição dos lugares é desigual. Desigualdade que se aprofunda, quando consideramos o litígio que se constitui entre lugares sociais de dizer distintos.

Como dissemos acima, o vocativo agencia alguém em alocutário-x na cena enunciativa do acontecimento de enunciação. Nesta medida, um nome como vocativo não é simplesmente um outro modo de dizer TU. $\mathrm{O}$ vocativo sobrepõe o funcionamento da designação como modo de constituir aquele que é agenciado como alocutário-x. Isto é claramente um funcionamento afetado pela história.

\section{Conclusão}

As gramáticas tratam o vocativo só como uma questão gramatical e consideram que o vocativo se dirige ao destinatário, ouvinte etc.

As abordagens retóricas incluem na questão do vocativo seu funcionamento no que se considera uma figura de retórica, a apóstrofe. Estas considerações acabam por mostrar que há, na apóstrofe, e assim no vocativo que a constitui, um movimento que faz passar como "intenção argumentativa" de uma terceira pessoa a uma segunda.

A nossa questão é outra: como se dá o funcionamento do vocativo e o que seu funcionamento significa? Um aspecto importante foi ver que não é só a apóstrofe que faz a passagem da terceira pessoa para a segunda. É próprio do funcionamento do vocativo significar o alocutário-x, ou seja, agenciar, a partir da designação, o lugar de um TU para o qual se diz. Exemplos interessantes para se ver isso é, no caso dos textos que analisamos, os vocativos Brasileiros! de JK e Brasileiras e Brasileiros de Sarney. O que fica claro é que estes vocativos, nos dois casos, só funcionam porque designam. Portanto, a própria construção do vocativo depende da relação de designação do nome. E isto se dá, de modo particularmente diferente, com o vocativo andorinha andorinha. E se dá, também de um outro modo, com os vocativos com o nome José no poema de Drummond.

Do ponto de vista do funcionamento da cena enunciativa, vemos que só é possível saber o lugar-social do locutor (1-x) e do alocutário (al-x) a partir do lugar do ELE, da terceira pessoa, da pessoa enquanto fora da relação de intercurso numa alocução qualquer. $\mathrm{Na}$ verdade, diz respeito à relação EU - ELE, da história, portanto. 


\section{Referências bibliográficas}

GUIMARÃES, E. Produzindo o sentido de um nome de cidade. RUA, número especial. Labeurb, 2014.

Ler um texto: uma perspectiva enunciativa. Revista da Abralin, v. 12, 2, ABRALIN, 2013.

Aposto e nome próprio. Entremeios, 5, Pouso Alegre, PPGCL, Univás, 2012.

Semântica do Acontecimento. Campinas: Pontes, 2002.

LAUSBERG, H. Manual de retórica literária. Madrid: Gredos, 1966.

PERELMAN, Ch.; TYTECA, L.O. Traité de l'Argumentation. Bruxelas: Editions de l’Université de Bruxelles, 1970.

RANCIÈRE, J. Os nomes da história. Campinas: Pontes; Educ, 1994.

Artigo recebido em: fevereiro de 2016.

Aprovado e revisado em: junho de 2016.

Publicado em: agosto de 2016

\section{Para citar este texto:}

GUIMARÃES, Eduardo. Vocativo: enunciação e história. Entremeios [Revista de Estudos do Discurso], Seção Estudos, Programa de Pós-graduação em Ciências da Linguagem (PPGCL), Universidade do Vale do Sapucaí, Pouso Alegre (MG), vol. 13, p. 169-180, jul. - dez. 2016.

DOI: http://dx.doi.org/10.20337/ISSN2179-3514revistaENTREMEIOSvol13pagina169a180 